\title{
EFFECTS OF ASPIRIN AND PHENYLBUTAZONE ON THE RABBIT BLASTOCYST
}

\author{
J. L. SCHARDEIN, E. T. WOOSLEY, L. E. HAMILTON \\ AND D. H. KAUMP
}

Research Division, Parke, Davis and Co., Ann Arbor, Michigan, U.S.A. (Received 30th December 1964, revised 15th March 1965)

The rabbit blastocyst has received but scant general use in evaluating the effects of drugs. Agents thus far evaluated have included hormones, colchicine derivatives, alkylating agents, vitamins and their antagonists, purine and pyrimidine analogues, and a variety of miscellaneous agents and drugs, including thalidomide and certain of its metabolites (Adams, Hay \& Lutwak-Mann, 1961; Lutwak-Mann \& Hay, 1962; Hay, 1964). It was the purpose of this experiment to determine the effects on the rabbit blastocyst of several drugs, and, further, to correlate parturition data with the blastocyst data.

The drugs employed were aspirin (at $150 \mathrm{mg} / \mathrm{kg}$ ) and phenylbutazone (at $126 \mathrm{mg} / \mathrm{kg}$ and $150 \mathrm{mg} / \mathrm{kg}$ ). Administration was by oral gavage with the compounds suspended in $10 \%$ aqueous acacia solution. Sham vehicle control (acacia) as well as untreated control animals were run in parallel. Following successful copulation by three untreated males, the treated does were medicated (Day 0 ) on this and the succeeding 6 days (seven doses).

In the blastocyst recovery portion of the experiment, fifty-five virgin, Little Dutch strain females were utilized, with an average weight of $2 \cdot 1 \mathrm{~kg}$. Additionally, eighteen does were treated in an identical manner during the first 7 days of the experimental period, but were killed near term at Day 31 (Day 0 as day of copulation). These animals had an initial average weight of $1.9 \mathrm{~kg}$.

Blastocysts were removed from the uterine horns at 6.5 days of age and prepared as flat mounts according to the technique of Moog \& Lutwak-Mann (1958). They were then staged according to the criteria described by Adams et al. (1961), measured and evaluated.

Table $I$ is a résumé of the treatment schedules employed and blastocyst recovery data.

Of the eighty-nine blastocysts from twenty-one inseminated does of the three control groups, normal microscopic variations were found which included minor trophoblastic vacuolation (Pl. 1, Fig. 1), trophoblastic 'degeneration granules' and trophoblastic 'knob' formations. A 'normal' blastocyst is pictured in Pl. 1, Fig. 2, and embryonic disc cells in Pl. 1, Fig. 3.

Ten does treated with phenylbutazone $(126 \mathrm{mg} / \mathrm{kg} \times 7)$ yielded seven litters composed of twenty-eight blastocysts. There was evidence of toxicity (weight 
loss) in two does, reduction in fertility and perhaps reduction in litter size. There were microscopic alterations of blastocysts of both the embryonic disc and supporting tissues in three litters. These included abnormal size variations, abnormally-shaped embryonic discs (Pl. 1, Fig. 4) including some with abnormal cells, severe vacuolation of the entire trophoblast (Pl. 1, Fig. 5), and abnormal mitotic figures.

TABLE 1

TREATMENT SCHEDULES AND BLASTOCYST DATA

\begin{tabular}{|c|c|c|c|c|c|c|c|}
\hline \multirow[b]{2}{*}{ Group } & \multirow[b]{2}{*}{ Treatment } & \multirow[b]{2}{*}{ No. } & \multicolumn{3}{|c|}{ Rabbits } & \multicolumn{2}{|c|}{ Blastocysts } \\
\hline & & & $\begin{array}{c}\text { Not } \\
\text { fertile }\end{array}$ & $\begin{array}{c}\text { Fertile } \\
\text { but no } \\
\text { blastocysts } \\
\text { recovered }\end{array}$ & $\begin{array}{c}\text { Fertile } \\
\text { with } \\
\text { blastocysts } \\
\text { recovered }\end{array}$ & $\begin{array}{l}\text { No. } \\
\text { recovered }\end{array}$ & $\begin{array}{l}\text { Mean } \pm \text { s.D. } \\
\text { rabbit }\end{array}$ \\
\hline 1 & Untreated controls & 9 & 1 & 0 & 8 & 42 & $5 \cdot 3 \pm 1 \cdot 2$ \\
\hline & $\begin{array}{l}\text { 1reated controls, seven } \\
\text { doses, } 10 \% \text { acacia at } \\
1.26 \mathrm{ml} / \mathrm{kg}\end{array}$ & 9 & 1 & 0 & 8 & 56 & $7 \cdot 0 \pm 1 \cdot 7$ \\
\hline 3 & $\begin{array}{l}\text { Treated controls, seven } \\
\text { doses, } 10 \% \text { acacia at } \\
1.5 \mathrm{ml} / \mathrm{kg}\end{array}$ & 9 & 0 & 1 & 8 & 49 & $5 \cdot 4 \pm 2 \cdot 2$ \\
\hline 4 & $\begin{array}{l}\text { Phenylbutazone, seven } \\
\text { doses at } 126 \mathrm{mg} / \mathrm{kg}\end{array}$ & 10 & 3 & 0 & 7 & 28 & $4 \cdot 0 \pm 2 \cdot 7$ \\
\hline 5 & $\begin{array}{l}\text { Phenylbutazone, seven } \\
\text { doses at } 150 \mathrm{mg} / \mathrm{kg}\end{array}$ & 9 & 2 & 3 & 4 & 8 & $1 \cdot 1 \pm 1 \cdot 5$ \\
\hline 6 & $\begin{array}{l}\text { Aspirin, seven doses at } \\
150 \mathrm{mg} / \mathrm{kg}\end{array}$ & 9* & 3 & 0 & 5 & 31 & $6 \cdot 2 \pm 2 \cdot 4$ \\
\hline
\end{tabular}

* One died, owing to intubation accident.

Of nine does treated with phenylbutazone $(150 \mathrm{mg} / \mathrm{kg} \times 7)$, there were only four litters composed of eight blastocysts. This reduction in fertility and fecundity was associated with evidence of toxicity as reflected by weight loss in three does. Further, this dose level would appear to be close to an abortifacient dose under the conditions of this experiment. There were microscopic alterations of blastocysts of two litters in both the embryonic disc and supporting tissues, which included size retardation of the disc, irregular embryonic discs (Pl. 1, Fig. 6), and moderate trophoblast cell vacuolation.

\section{EXPLANATION OF PLATE 1}

Frg. 1. Normal blastocyst. Cells of the trophoblast with 'normal' vacuolation and with few mitotic figures. $\times 175$.

FIG. 2. Normal blastocyst with normal embryonic disc surrounded by trophoblast. $\times 7 \cdot 5$.

Fig. 3. Normal blastocyst showing embryonic disc cells. $\times 175$.

Frg. 4. Phenylbutazone treated doe. Abnormal embryonic disc (compare with Fig. 2). $\times 15$.

Fig. 5. Phenylbutazone treated doe. Severe vacuolation of trophoblast cells (compare with Fig. 1). $\times 175$.

Fig. 6. Phenylbutazone treated doe. Abnormal embryonic disc (compare with Fig. 2). $\times 15$.

Fig. 7. Aspirin treated doe. Degenerate cells of embryonic disc (compare with Fig. 3) $\times 175$. Frg. 8. Aspirin treated doe. Trophoblast, with decreased mitotic figures and distorted cell nuclei (compare with Fig. 1). $\times 175$. 
PI.ATE 1
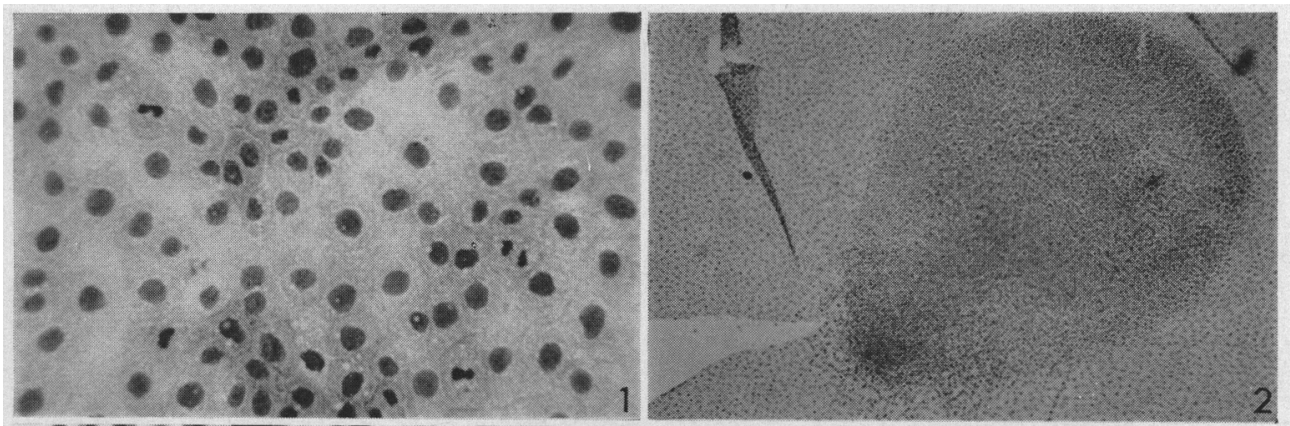

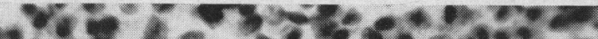

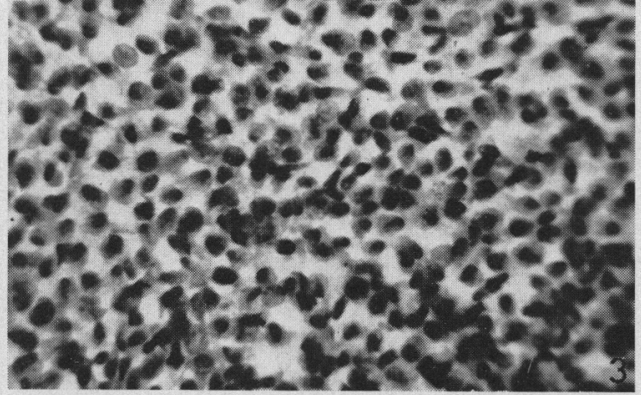
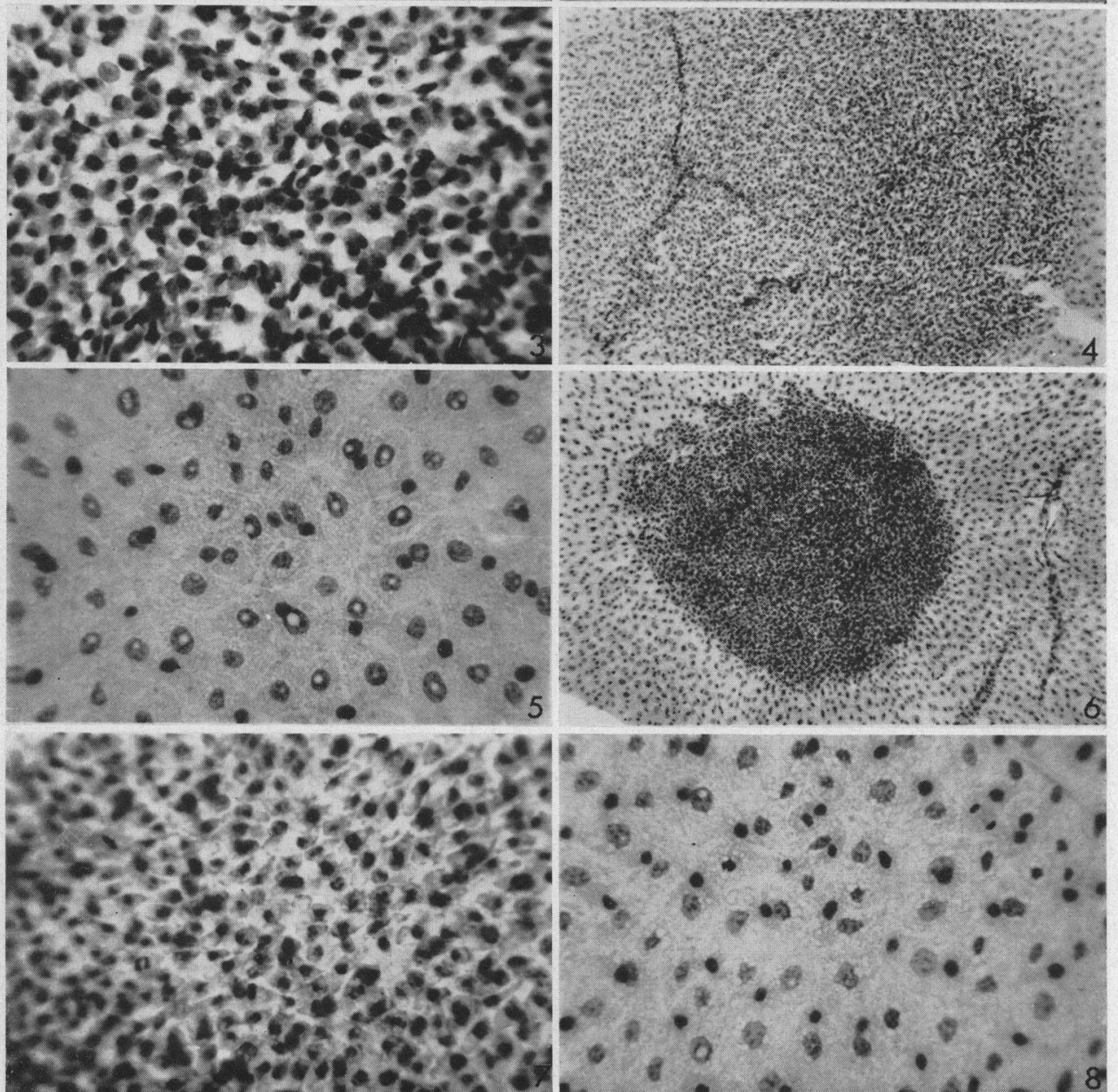

(liacing p. 130) 
Of nine does treated orally with aspirin $(150 \mathrm{mg} / \mathrm{kg} \times 7)$, there were five litters containing thirty-one embryos. There was reduced fertility, but the litter sizes were comparable to the control groups. Blastocysts of four litters had microscopic alterations in both embryonic disc and supporting tissues. These included abnormal embryonic discs, consisting of size retardation, abnormal shapes or degenerate disc cells (Pl. 1, Fig. 7), excessive vacuolation of the trophoblast, apparent decreased mitotic activity of the trophoblast and distorted trophoblast cell nuclei (Pl. 1, Fig. 8).

Of nine does killed 31 days after receiving phenylbutazone $(150 \mathrm{mg} / \mathrm{kg} \times 7)$ in conditions comparable to that of Group 5, there was a reduction both in litters and in litter size, but with no gross anomalies of the offspring. These data are summarized in Table 2.

TABLE 2

PARTURITION DATA IN DRUG-TREATED AND VEHICLE-TREATED FEMALE RABBITS KILLED AT TERM

\begin{tabular}{|c|c|c|c|c|c|c|c|c|c|}
\hline \multirow{3}{*}{ Treatment $(7 \times)$} & \multirow{3}{*}{$\begin{array}{l}\text { Females } \\
\text { with kits } \\
\text { |females } \\
\text { inseminated }\end{array}$} & \multicolumn{8}{|c|}{ Autopsy data (average/litter) } \\
\hline & & \multirow{2}{*}{ Live } & \multirow{2}{*}{ Dead } & \multirow{2}{*}{ Resorption } & \multirow{2}{*}{ Abnormal } & \multicolumn{2}{|c|}{ Sex } & \multicolumn{2}{|c|}{ Foetal wt $(g)$} \\
\hline & & & & & & 우 & 0 & 우 & $\sigma$ \\
\hline \multirow{2}{*}{$\begin{array}{l}1.5 \mathrm{ml} / \mathrm{kg} \text { Acacia } \\
\text { control } \\
150 \mathrm{mg} / \mathrm{kg} \\
\text { phenylbutazone }\end{array}$} & $7 / 9^{*}$ & $5 \cdot 3$ & 0 & $1 \cdot 6$ & 0 & $2 \cdot 8$ & $3 \cdot 3$ & 40 & 39 \\
\hline & $6 / 9$ & $3 \cdot 5$ & 0.2 & 1.7 & 0 & $2 \cdot 0$ & $2 \cdot 3$ & 43 & 41 \\
\hline
\end{tabular}

* One doe died prematurely, and seven dead foetuses were found in utero. This animal was not included in the category of 'female with kits'.

In other rodents, it has been shown (Klein Obbink \& Dalderup, 1964) that high doses of acetylsalicylic acid produce a marked increase in embryonic mortality, either as stillbirths (mice) or resorption (rats) in litters at term. Further, in rats, reduced litter size and skeletal aberrations of the foetuses have been reported (McColl, Globus \& Robinson, unpublished data).

The observations made on the 6.5-day blastocyst of the phenylbutazonetreated does $(150 \mathrm{mg} / \mathrm{kg})$, in this experiment, would appear to be in some part suggestive of the fate of pregnancy when carried to term. The low recovery and damage to blastocysts correlated with and supported the reduced fertility and fecundity at parturition. The interpretation of the histologic alterations encountered in the 6.5 -day blastocyst was not made clear by this study, since no gross anomalies were noted.

The authors wish to thank Mr Ralph Hartnagel, Jr. for the photomicrographs. 


\section{REFERENCES}

Adams, C. E., Hay, M. F. \& Lutwak-Mann, C. (1961) The action of various agents upon the rabbit embryo. 7. Embryol. exp. Morph. 9, 468.

HAY, M. F. (1964) Effects of thalidomide on pregnancy in the rabbit. 7. Reprod. Fertil. 8, 59.

Klein Obbink, H. J. \& Dalderup, L. M. (1964) Effect of acetylsalicylic acid on foetal mice and rats. Lancet, $\mathbf{i}, 565$.

Lutwax-ManN, G. \& Hay, M. F. (1962) Effect on the early embryo of agents administered to the mother. Brit. med. F. ii, 944.

Moog, F. \& LUTWAK-MANN, C. (1958) Observations on rabbit blastocysts prepared as flat mounts. 7. Embryol. exp. Morph. 6, 57. 